\title{
List of scientific participants of the meeting
}

Anna-Carin ANDERSSON

François BALLOUX

Agata BANASZEK

Larisa S. BILTUEVA

Joanna BOLTRUSZKO

Pavel M. BORODIN

Nina S. BULATOVA

Natalia BYSTRAKOVA
Department of Genetics, Uppsala University Box 7003, SE-750 07 Uppsala, Sweden E-mail: annacarin.andersson@genetik.uu.se Institut d'Ecologie, Laboratoire de Zoologie et d'Ecologie Animale, Bâtiment de Biologie, Université de Lausanne, 1015 Lausanne-Dorigny, Switzerland

E-mail: Francois.Balloux@ie-zea.unil.ch

Institute of Biology, University of Białystok Świerkowa St. 20 B, 15-950 Białystok, Poland E-mail: banaszek@cksr.ac.bialystok.pl

Institute of Cytology and Genetics, Russian Academy of Sciences

Lavrentieva 10, Novosibirsk, 630090, Russia E-mail: bilar@bionet.nsc.ru

Institute of Biology, University of Białystok Świerkowa St. 20 B, 15-950 Białystok, Poland

Institute of Cytology and Genetics, Russian Academy of Sciences

Lavrentieva 10, Novosibirsk, 630090, Russia E-mail: borodin@bionet.nsc.ru

Present address:

Institute of Biology, Federal University of Rio de Janeiro Caixa Postal 68011, Rio de Janeiro, RJ, CEP 21944-970, Brazil

E-mail: borodine@acd.ufrj.br

Severtzov Institute of Ecology and Evolution, Russian Academy of Sciences,

33 Leninsky Prospect, 117071 Moscow, Russia E-mail:ninbul@yahoo.com

Zoology Department, Penza University Lermontova St. 37, Penza 440026, Russia E-mail: ermakov@penza.com.ru 
Włodzimierz CHĘTNICKI

Stanislaw FEDYK

Jacques HAUSSER

Denis M. LARKIN

Nicolas LUGON-MOULIN

Alina V. MISHTA

Magdalena MOSKA

Dorota OCHOCIŃSKA

Victor N. ORLOV
Institute of Biology, University of Białystok Świerkowa St. 20 B, 15-950 Białystok, Poland E-mail:wlodek@noc.uwb.edu.pl

Institute of Biology, University of Białystok Świerkowa St. 20 B, 15-950 Białystok, Poland E-mail: banaszek@cksr.ac.bialystok.pl

Institut d'Ecologie, Laboratoire de Zoologie et d'Ecologie Animale, Bâtiment de Biologie, Université de Lausanne, 1015 Lausanne-Dorigny, Switzerland E-mail: Jacques.Hausser@ie-zea.unil.ch

Institute of Cytology and Genetics, Russian Academy of Sciences

Lavrentieva 10, Novosibirsk, 630090, Russia E-mail: lark@bionet.nsc.ru

Institut d'Ecologie, Laboratoire de Zoologie et d'Ecologie Animale, Bâtiment de Biologie, Université de Lausanne, 1015 Lausanne-Dorigny, Switzerland E-mail: Nicolas.Lugon-Moulin@ie-zea.unil.ch

Schmalhausen Institute of Zoology, Ukrainian Academy of Sciences

B. Khmelnitsky St. 15, Kiev -30, 252601, Ukraine

E-mail: alina@mishta.pp.kiev.ua

Institute of Zoology, University of Wrocław ul. Sienkiewicza 21, 50-335 Wrocław, Poland E-mail: moskam@biol.uni.wroc.pl

Institute of Biology, University of Białystok Świerkowa St. 20 B, 15-950 Białystok, Poland E-mail:doroc@noc.uwb.edu.pl

Laboratory of Mammalian Microevolution, Severtzov Institute of Ecology and Evolution, Russian Academy of Sciences, 33 Leninsky Prospect, 117071 Moscow, Russia E-mail: sevin@glas.apc.org 
Polina L. PERELMAN

Jaroslav PIÁLEK

Andrei V. POLYAKOV

Zdzislaw PUCEK

Miroslaw RATKIEWICZ
Institute of Cytology and Genetics, Russian Academy of Sciences

Lavrentieva 10, Novosibirsk, 630090, Russia

E-mail:pol@bionet.nsc.ru

Institute of Vertebrate Biology,

Academy of Sciences of the Czech Republic

CZ-675 02 Studenec 122, Czech Republic

E-mail: jpialek@brno.cas.cz

Institute of Cytology and Genetics, Russian Academy of Sciences

Lavrentieva 10, Novosibirsk, 630090, Russia

E-mail: polyakov@bionet.nsc.ru

Mammal Research Institute,

Polish Academy of Sciences

17-230 Białowieża, Poland

E-mail:zpucek@bison.zbs.bialowieza.pl

Institute of Biology, University of Białystok Świerkowa St. 20 B, 15-950 Białystok, Poland E-mail: ermi@cksr.ac.bialystok.pl

Margarita B. ROGATCHEVA Institute of Cytology and Genetics, Russian Academy of Sciences

Lavrentieva 10, Novosibirsk, 630090, Russia

Present address:

Laboratory of Animal Management, School of Agricultural Sciences, Nagoya University, Nagoya 464-01, Japan E-mail: rogatchrita@hotmail.com

Ireneusz RUCZYŃSKI Mammal Research Institute, Polish Academy of Sciences 17-230 Białowieża, Poland E-mail: iruczyns@bison.zbs.bialowieza.pl

Leszek RYCHLIK
Mammal Research Institute, Polish Academy of Sciences

17-230 Białowieża, Poland

E-mail: lrychlik@bison.zbs.bialowieza.pl 
Jeremy B. SEARLE

Katarzyna SZAŁAJ

Elwira SZUMA

Krzysztof TURLEJSKI

Vitaly T. VOLOBOUEV

Anna M. WóJCIK

Jan M. WÓJCIK

Hanna ZALEWSKA
Department of Biology, University of York PO Box 373, York YO10 5YW, U.K.

E-mail: jbs3@york.ac.uk

Institute of Biology, University of Białystok Świerkowa St. 20 B, 15-950 Białystok, Poland E-mail: kszalaj@noc.uwb.edu.pl

Mammal Research Institute, Polish Academy of Sciences

17-230 Białowieża, Poland

E-mail: eszuma@bison.zbs.bialowieza.pl

Laboratory of Neurobiology of Development and Evolution, Nencki Institute of Experimental Biology, Polish Academy of Sciences Pasteura St. 3, 02-093 Warsaw, Poland E-mail: krist@ameba.nencki.gov.pl

Muséum National d'Histoire Naturelle, Laboratoire de Zoologie, Mammifères et Oiseaux, 55, rue Buffon, 75005 Paris Cedex 05, France

E-mail: vitaly@cimrs1.mnhn.fr

Mammal Research Institute, Polish Academy of Sciences 17-230 Białowieża, Poland E-mail: awojcik@bison.zbs.bialowieza.pl

Mammal Research Institute, Polish Academy of Sciences 17-230 Białowieża, Poland E-mail: jwojcik@bison.zbs.bialowieza.pl

Mammal Research Institute, Polish Academy of Sciences 17-230 Białowieża, Poland E-mail: zalewska@bison.zbs.bialowieza.pl 